\title{
An Empirical Study on Users' Perception Towards E-Learning Platforms
}

\author{
Smitha Sambrani
}

\begin{abstract}
The current scenario e-learning approach got prominence during the covid-19 pandemic. Many institutions were greatly dependent on e-learning platforms like Edx, Coursera, Udemy, Swayam, Webex, Zoom, Google meet etc. to teach their students and also it became a major part of the education system. The purpose of the study is to identify the perception of learners and accordingly suggest faculty community and technology developing companies. In this context, the current study aims to measure the learners' perception towards e-learning with five dimensions are Usefulness, Ease-of-Use, Self-Efficacy, Attitude \& Intention to Use, especially to measure at capital city of Telangana, namely Hyderabad. The learners' awareness of e-learning platforms is also examined along with the above variables. The hypothesis of the study is only one, 'which is there is no significance of users' perception found towards Usefulness, Ease-of-Use, Self-Efficacy, Attitude \& Intention to Use etc. aspects of electronic Learning Approach'. Research has been carried out as a descriptive study basing on primary and secondary data sources and also with the help of a structured questionnaire, 121 learners have been examined. These learners are identified based on their availability and conducted a structured interview, in some cases its telephone interview and mail response. Thirty research articles were reviewed in the construction of a theoretical framework. To collect the responses, the convenience non-random sampling technique was used and has applied both the descriptive statistics and t-test to analyze data. The greater part of responders felt it is more useful, easy to use, it improves self-efficacy; they also have shown a positive attitude towards the e-learning approach. A high level of intention is shown towards the e-learning approach and platforms.
\end{abstract}

Keywords: Learners' Perception, E-Learning, e-Learning Platforms

\section{INTRODUCTION}

Deliberate usage of electronic media and Information and Communication Technologies (ICT) in training and learning measures (Naidu 2006) is insinuated as e-acknowledging, where "e" signifies "electronic". It can in like manner be portrayed by various terms including electronic learning, online learning, appropriated education, association and e-learning. E-learning consolidates all enlightening activities did by individuals/bundles dealing with the web/separated

Manuscript received on August 12, 2021.

Revised Manuscript received on September 30, 2021.

Manuscript published on September 30, 2021

*Correspondence Author

Dr. Smitha Sambrani*, Associate Professor, Department Business of Management, The University College of Commerce and Business Management, Hyderabad (Telangana), India. Email: smithasambrani@yahoo.com

(C) The Authors. Published by Blue Eyes Intelligence Engineering and Sciences Publication (BEIESP). This is an open access article under the CC BY-NC-ND license (http://creativecommons.org/licenses/by-nc-nd/4.0/) and all the while/no simultaneously through association/free PCs and electronic devices.

E-learning is a storage facility of instruction, data, correspondence, preparing, and information and execution on the board. Presently a day in instructing and learning has made a need to change understudies by utilizing current viable courses as E-Learning.

E-Learning acts have an interface among understudies and their learning targets. E-learning climate can be gotten to by utilizing an internet browser to access the web or intranet. E-learning helps in giving adapting anyplace whenever dependent on the student premium. The development in the field of current data correspondence advancements has reformed the regions differing from language figuring out how to language use. Instructing and learning techniques in training have been expanded for giving schooling through the use of E-Learning through data innovation.

E-Learning empowers higher intuitiveness among teachers and understudies and study material inclusion in both undergrad/graduate understudies. Further, educators and colleagues guarantee that understudies basic reasoning is created, and to give them the opportunity in conversation, subjects decision, trade of thoughts and data and extension of information.

Types of e-Learning: 1. Synchronous learning: Synchronous learning is much the same as homeroom learning aside from that the teacher and all the students could each be in a unique area. This kind of E-learning is appropriate for idea based preparing, preparing exceptionally complex ideas and now and again preparing for students who require the presence of a coach. This kind of learning happens through virtual homerooms, Chat, online courses, application sharing. Asynchronous learning: Generic preparing that has a long period of usability and doesn't relate to a specific gathering of individuals, for example, delicate abilities preparing, the executives preparing, and monetary preparing can be directed through non-concurrent e-learning. Offbeat learning utilizes media that isn't immediate through messages sheets, messages, web journals, CDs and DVDs, self-guided online courses. 3. Blended learning: Blended learning is a blend of coordinated and non-concurrent learning. The extent of every one of the mixed fixings will rely upon the crowd, the measure of autonomy and direction needed during the preparation/learning. Mixed learning can likewise be a mix of disconnected and online courses, independent and synergistic learning, work and learning.

Published By:

Blue Eyes Intelligence Engineering

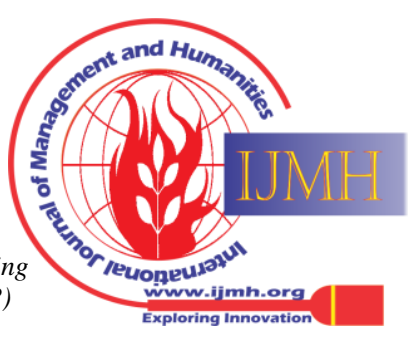




\section{REVIEW OF LITERATURE}

"Ancapopovivi" "CosminaMironov" in the article "Student's perception on using E-Learning technologies (2018)" studied the perception of students towards E-Learning technologies. Findings concluded in saying that students have finely outfitted in utilizing technology and using technologies to support the learning process and such approach is supported mainly by teachers. "Dr Gunamalasuri" " Snehasharma" in the article "the impact of gender on attitude towards computer technology and E-Learning (2016)" studied the effect of sexual orientation and impact of sex on utilization of PC innovation and E-learning structures. This article study satisfied the target of understanding the effect of sexual orientation on PC demeanour and E-learning and the examination concluded that there is no contrast between the attitudinal scores of guys and females because the two guys and females are particular towards the different types of E-Learning. "Sarkahubackova" in the article "Motivation in e-learning in university (2015)" studied the motivational factors responsible for students to prefer E-Learning over traditional learning. The article concluded that the strongest reason for the choice of language is still the study program of the faculty. "sarkahubackova" in the article "History and perspectives of E-Learning (2014)" studied the history and the development, technical improvement in E-Learning. The author concluded that new methods were created not only to educate, also facilitate the information sharing among teacher, leaners and the student. "AzlizaYacoba" "AiniZuriyati" "Abdul Kadirb" "O. Zainudinc" “A. Zurairahd" in the article "Student awareness towards ELearning in education (2011)" This article analyzes the familiarity with e-discovering that includes understudies from TATI University school. Different relapses have been applied on the understudy insights according to sexual orientation, year of study, innovation and mindfulness towards e-learning. The outcomes indicated that there is huge mindfulness towards e-learning in that college." Hassan M. Selim" in the article "critical success factors for e-learning acceptance confirmatory factor models (2005)" learned about the basic elements as seen my college understudies and arranged into 4 variables Instructor, understudy, data innovation, and college uphold. The outcomes appeared by understudies there are 8 basic determinants of e-learning acknowledgement. "Jennifer $\mathbf{C}$. Richardson" "Karen Swan" in the article "Examine social presence in online courses concerning students perceived learning and satisfaction(2003)" study investigated the part of social activeness in internet studying conditions and its association to understudies "impression of learning and fulfillment with the teacher". The examination identified that understudies with a greater impression of social activeness and scored greater terms of apparent educating and saw fulfillment with educators and found that sex doesn't assume a critical part. "Liyan Song" "Ernise S. Singleton" "Janette R. Hill" "MyungHwa" in the article "Improving online learning: Student perceptions of useful and challenging characteristics (2003)" the investigation was to acquire bits of knowledge into student's impression of the internet learning. The aftereffects of the investigation presumed that most students concurred that course plan, student inspiration, time management, and ease with online innovations sway the achievement of web-based education knowledge. "Michael C. Rodriguez" "Ann Ooms" "Marcel Montanez" in the article "Students' Perceptions of Online-learning Quality given Comfort, Motivation, Satisfaction, and Experience (2003)" the investigation was to think about the internet learning has given any solace inspiration and experience. The outcome demonstrated that for understudies with the mixture learning experience, comfort was identified with inspiration and saw quality. Inspiration was identified with fulfillment, and fulfillment was identified with apparent quality. It likewise demonstrated that understudies with no web-based learning encounters, comfort was identified with inspiration and different variables were identified with the apparent nature of online courses. "Karl L. Smart" and "James J. Cappel" in the article "Student's Perceptions of Online Learning: A Comparative Study (2006)" the study examines the student's perception of integrated online components in which, before the classroom discussion itself students are finishing e-learning modules. The comparative study result is overall satisfaction and subject perception of these online units. And the study found that there are differences in perception based on demographic factors in addition, perceived benefits of the online units.

\section{OBJECTIVE AND HYPOTHESIS}

The main aim of the research is to measure learners' perception towards e-learning with five dimensions that are Usefulness, Ease-of-Use, Self-Efficacy, Attitude \& Intention to Use, especially to measure at Hyderabad city.

The hypothesis of the study is only one, 'which is there is no significant of users' perception found towards Usefulness, Ease-of-Use, Self-Efficacy, Attitude\& Intention to Use etc. aspects of electronic Learning Approach'

\section{RESEARCH METHODOLOGY}

The present research is Descriptive in nature. To meet the objectives, techniques related to both the Qualitative \& quantitative have been used. The collection of primary data has done using a structured questionnaire amongst professional college students.

Table 1: Elements and Description of Research Methodology

\begin{tabular}{|l|l|}
\hline Elements of the Methodology & Description of Methodology \\
\hline Name of the research & Descriptive study \\
\hline locality & Hyderabad City \\
\hline Size of the sample & 121 people \\
\hline Source of Data & Primary and Secondary Sources \\
\hline Technique for Sample Selection & Convenient N0N-Random Sample \\
\hline Techniques used to collect data & Structured Questionnaire. \\
\hline Measurement Scale & Likert 5- point scale \\
\hline Data Analysis Methods & $\begin{array}{l}\text { Descriptive Statistics \&0ne } \\
\text { Sample T-Test }\end{array}$ \\
\hline
\end{tabular}

(Researcher's Compliance)

Published By:

Blue Eyes Intelligence Engineering and Sciences Publication (BEIESP) 32 (C) Copyright: All rights reserved. 


\section{V.DATA ANALYSIS AND INTERPRETATIONS}

A. Awareness of e-Learning:

Table 2: Frequencies of Awareness on E-Learning Platforms

\begin{tabular}{|l|l|l|l|l|l|}
\hline & & Frequency & Percent & $\begin{array}{l}\text { Valid } \\
\text { Percent }\end{array}$ & $\begin{array}{l}\text { Cumulative } \\
\text { Percent }\end{array}$ \\
\hline \multirow{3}{*}{ Valid } & No & 2 & 1.7 & 1.7 & 1.7 \\
\cline { 2 - 6 } & Yes & 119 & 98.3 & 98.3 & 100.0 \\
\cline { 2 - 6 } & Sum & 121. & 100 & 100 & \\
\hline
\end{tabular}

(Researcher's Compliance)

From the above table-2, a total of 119 members are aware of e-learning from the sample of 121 members. It is 98.3 per cent of the total sample. Just 2 members are unaware of the e-learning platforms. It is a very nominal number. A greater amount of awareness on e-learning is existing.

\section{B. Do You Believe You Can Have Live Lectures Over the Internet as It Is Done in The Classroom?}

Table 3: Frequencies of The Liveliness of Lectures

\begin{tabular}{|l|l|l|l|l|l|}
\hline & & Frequency & $\%$ & Valid \% & $\begin{array}{c}\text { Cumulati } \\
\text { ve \% }\end{array}$ \\
\hline \multirow{7}{*}{ Val } & -DA (Disagree) & 1 & 0.8 & 0.8 & 0.8 \\
\cline { 2 - 6 } & $\begin{array}{l}\text { Neither -Agree } \\
\text { nor DA }\end{array}$ & 2 & 1.7 & 1.7 & 2.5 \\
\cline { 2 - 6 } & -Agree & 77 & 63.6 & 63.6 & 66.1 \\
\cline { 2 - 6 } & Strongly-Agree & 41 & 33.9 & 33.9 & 100.0 \\
\cline { 2 - 6 } & Sum & 121 & 100.0 & 100.0 & \\
\hline
\end{tabular}

(Researcher's Compliance)

From the above table-3, a Total of 118 members are agreed that the live lectures over the internet as it is done in the classroom will have the same live experience. Is 96 per cent of respondents are agreeing to the above statement. Very few respondents have given opinions of disagreeing and strongly disagree statements. It means they believe that the equal level of the liveliness of lectures over the internet as it is done in the classroom.

\section{Learning Effectively and Easy Access to Learning Materials:}

Table 4: Frequencies of Learning Effectively and Easy Access to Materials

\begin{tabular}{|c|c|c|c|c|c|}
\hline & Frequency & Per-cent & $\begin{array}{c}\text { Valid } \\
\text { Percent }\end{array}$ & $\begin{array}{c}\text { Cumulative } \\
\text { Per-cent }\end{array}$ \\
\hline \multirow{7}{*}{ Valid } & $\begin{array}{c}\text { Strongly } \\
\text { Disagree. }\end{array}$ & 2 & 1.7 & 1.7 & 1.7 \\
\cline { 2 - 6 } & $\begin{array}{c}\text { Disagree. } \\
\text { Agree } \\
\text { Disagree. }\end{array}$ & 9 & 7.4 & 7.4 & 9.1 \\
\cline { 2 - 6 } & $\begin{array}{c}\text { Neither } \\
\text { Agree. }\end{array}$ & 34 & 28.1 & 28.1 & 38 \\
\cline { 2 - 6 } & $\begin{array}{c}\text { Strongly } \\
\text { Agree. }\end{array}$ & 75 & 62 & 62 & 100 \\
\cline { 2 - 6 } & Sum. & 121 & 100 & 100 & 9.9 \\
\hline
\end{tabular}

(Researcher's Compliance)
From the above table-4, a Total of 110 members is agreed to the above statement. Is 90 percentages of them are answered that studying through the e-learning method would increase my studying effectively, as I will have easy access to learning materials. It is positively reflecting on the learning process online.

\section{Null Hypothesis-1:}

There is no significant difference in users' perception found towards Usefulness, Ease-of-Use, Self-Efficacy, Attitude \& Intention to Use etc. aspects of the electronic Learning Approach.

Table 5: Statistics of One-Sample T-Test

\begin{tabular}{|c|c|c|c|c|}
\hline & $\mathrm{N}$ & .Mean & $\begin{array}{c}\text {.Std. } \\
\text { Deviation }\end{array}$ & $\begin{array}{c}\text {.Std. Error } \\
\text { Mean }\end{array}$ \\
\hline Usefulness & 121 & 3.9963 & 0.50273 & 0.0457 \\
\hline Ease of Use & 121 & 4.3554 & 0.50182 & 0.04562 \\
\hline Self-Efficacy & 121 & 3.8198 & 0.61069 & 0.05552 \\
\hline Attitude & 121 & 4.1818 & 0.43436 & 0.03949 \\
\hline Intention to Use & 121 & 4.3609 & 0.47451 & 0.04314 \\
\hline
\end{tabular}

(Researcher's Compliance)

From the above table, the mean value of aspects of e-learning is Usefulness with 3.99, Ease of Use with 4.35, Self-Efficacy with 3.81, Attitude with 4.15 and Intention to Use with 4.36. The mean values of all the dimensions are found more than 3 mean. It shows that the perception of learners is somewhat favourable to the e-learning approach.

Table 6: Test Statistics of One-Sample T-Test

\begin{tabular}{|c|c|c|c|c|c|c|}
\hline & \multicolumn{6}{|c|}{.Test Value $=3$} \\
\hline & \multirow[t]{2}{*}{$t$} & \multirow[t]{2}{*}{$\mathrm{Df}$} & \multirow[t]{2}{*}{ Sign. (2 tailed) } & \multirow[t]{2}{*}{$\begin{array}{c}\text { mean } \\
\text { difference }\end{array}$} & \multicolumn{2}{|c|}{$\begin{array}{l}\text { (a) } 95 \% \text { Confidence- } \\
\text {.Interval of the } \\
\text { Difference- }\end{array}$} \\
\hline & & & & & -Lower- & -Upper- \\
\hline Usefulness & 21.8 & 120 & 0 & 0.99631 & 0.9058 & 1.0868 \\
\hline Ease of Use & 29.71 & 120 & 0 & 1.35537 & 1.265 & 1.4457 \\
\hline Self-Efficacy & 14.767 & 120 & 0 & 0.81983 & 0.7099 & 0.9298 \\
\hline Attitude & 29.929 & 120 & 0 & 1.18182 & 1.1036 & 1.26 \\
\hline $\begin{array}{c}\text { Intention to } \\
\text { Use }\end{array}$ & 31.548 & 120 & 0 & 1.36088 & 1.2755 & 1.4463 \\
\hline
\end{tabular}

(Researcher's Compliance)

From the above table of one sample t-test -6 , All the dimensions of learners' perception significant values have presented lesser to the p-value i.e., 0.05. Therefore, rejected the null hypothesis and accepted the alternative hypothesis. Hence a significant level of learners' perception is found among the dimension of perception that is Usefulness, Ease of Use, Self-Efficacy, Attitude and Intention to Use.

\section{CONCLUSION}

The covid-19 pandemic was open doors for e-learning platforms, not only it many technology-based products, which are support work from home. Similarly, education institutions were merely dependent on e-learning platforms like Edx, Coursera, Udemy,

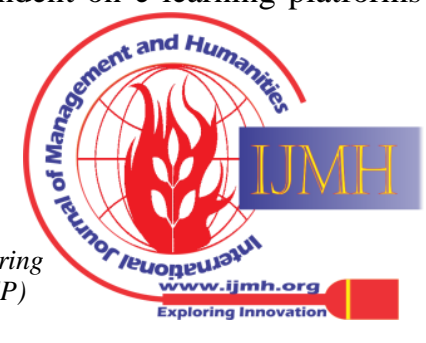




\section{An Empirical Study on Users' Perception Towards E-Learning Platforms}

Swayam etc. Also, institutions were greatly dependent on online platforms to teach the students. In this context, the study is got a prominent level of significance in modern learning. Maximum numbers of learners are aware of it, they have accepted e-learning platforms, also felt that it cangive more privileges than compared with the off-line learning method. In this study majority of the sample out of 121 , accepted the above statements. There is a significant level of perception found among the dimension of e-learning that is Ease-of-Use, Usefulness, Self-Efficacy, Attitude \& Intention to Use etc. aspects of the electronic Learning Approach. It indirectly shows that the adoption and acceptance of learners towards the e-learning approach are highly positive. They felt it is more useful, easy to use and approach, it improves self-efficacy, they also have shown a positive attitude towards e-learning approach, high level of intention is shown towards e-learning approach and platforms.

\section{APPENDIX}

It is optional. Appendixes, if needed, appear before the acknowledgment.

\section{ACKNOWLEDGMENT}

It is optional. The preferred spelling of the word "acknowledgment" in American English is without an "e" after the "g." Use the singular heading even if you have many acknowledgments. Avoid expressions such as "One of us (S.B.A.) would like to thank ...." Instead, write "F. A. Author thanks" Sponsor and financial support acknowledgments are placed in the unnumbered footnote on the first page.

\section{REFERENCES}

1. Popovici, A., \&Mironov, C. (2018). Students' perception on using eLearning technologies. Procedia-Social and Behavioral Sciences, 180, 1514-1519.

2. Suri, G., \& Sharma, S. (2016). The impact of gender on attitude towards computer technology and e-learning: An exploratory study of Punjab University, India. International Journal of Engineering Research, 2(2), 132-136.

3. Hubackova, S. (2015). History and perspectives of learning. Procedia-Social and Behavioral Sciences, 191, 1187-1190.

4. Yacob, A., Kadir, A. Z. A., Zainudin, O., \&Zurairah, A. (2012) Student awareness towards e-learning in education. Procedia-Social and Behavioral Sciences, 67, 93-101.

5. Selim, H. M. (2007). Critical success factors for e-learning acceptance: Confirmatory factor models. Computers \& Education, 49(2), 396-413.

6. Richardson, J., \& Swan, K. (2003). Examing social presence in online courses concerning students' perceived learning and satisfaction.

7. Song, L., Singleton, E. S., Hill, J. R., \&Koh, M. H. (2004). Improving online learning: Student perceptions of useful and challenging characteristics. The internet and higher education, 7(1), 59-70.

8. Rodriguez, M. C., Ooms, A., \&Montañez, M. (2008). Students' perceptions of online learning quality given comfort, motivation, satisfaction, and experience. Journal of interactive online learning, 7(2), 105-125.

9. Smart, K. L., \&Cappel, J. J. (2006). Students' perceptions of online learning: A comparative study. Journal of Information Technology Education: Research, 5(1), 201-219.

10. A.BINDHU, (2016), "INFLUENCE OF LEARNER CHARACTERISTICS ON E-LEARNING OUTCOMES", ANVESHANA'S INTERNATIONAL JOURNAL OF RESEARCH IN REGIONAL STUDIES, LAW, SOCIAL SCIENCES, JOURNALISM AND MANAGEMENT PRACTICES, AIJRRLSJM VOLUME 1, ISSUE 8 (2016, SEPT) (ISSN-2455-6602) ONLINE

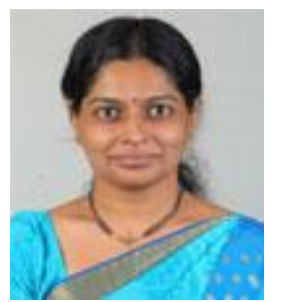

\section{AUTHORS PROFILE}

Dr. Smitha Sambrani (B.E., M.B.A., Ph.D.) Associate Professor, Department of Business Management, Osmania University, Hyderabad, Telangana, India.

Dr. Smitha Sambrani: She holds a B.E degree in Electronics and Communication Engineering from Osmania University, College of Engineering (1994), with Distinction and an M.B.A from Osmania University, College of Commerce \& Business Management (1996). She was awarded the Doctorate Degree in Management from Osmania University (2006), for her thesis titled 'The impact of Information Technology on banking sector - A study of select banks'. She has qualified the National Eligibility Test for Lectureship and is a recipient of the Junior Research Fellowship. She has over 22 years experience in both industry and academics combined. She has around 50 publications to her credit in reputed national journals and has presented more than two dozen papers at national and international seminars. Her areas of interest include Marketing, General Management and Business Research. She is widely traveled and has visited The Kingdom of Saudi Arabia, Singapore, Nepal, Dubai and Sri Lanka. Currently she is Assistant Professor at Department of Business Management, Osmania University
Published By:

Blue Eyes Intelligence Engineering and Sciences Publication (BEIESP)

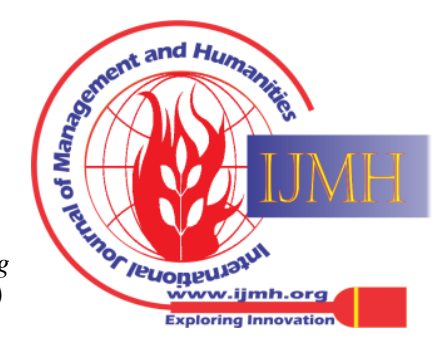

